\title{
Evaluation of the Plant Growth Promoting Potential of Endophytic Bacteria Isolated from Vigna radiata (L)
}

\author{
Nidhi Gujar ${ }^{1 *}$, Tanuja Murab ${ }^{1}$ and Preeti Chandurkar ${ }^{1}$ \\ Department of Biotechnology, Career college, Bhopal, India ${ }^{l}$. \\ E-mail: nidhigujar81@gmail.com
}

\begin{abstract}
Vigna radiata (Mung bean) is one of the major pulse crop cultivated in Madhya Pradesh. Endophytic bacteria are endosymbiotic and offer benefits to host plant. A total of 25 endophytic bacteria were isolated from roots nodules of Vigna radiata from Misrod District Bhopal, M.P during summer season. These were assessed for plant growth promoting traits. Among all the endophytes $72 \%$ of the isolates were positive for IAA ptoduction ranging from $1.02-44.24 \mu \mathrm{g} / \mathrm{ml}$. Siderophore production ranged between 0.09 to $5.22 \mathrm{mg} / \mathrm{ml}$ with $60 \%$ of the isolates as positive. $36 \%$ of the bacterial endophytes were positive for Phosphate solubilisation and ammonia production. ACC deaminase activity and HCN production was observed by $52 \%$ of the isolates. $32 \%$ of the endophytes showed antagonistic activity against the fungal pathogens. Isolate VRN 7, VRN10 and VRN 15 showed antagonistic activity against all the tested fungal pathogens. The bacterial endophytes possessed multiple growth promoting traits along with resistance to varying temperature, $\mathrm{pH}$ and salinity conditions thus ideal for use in field for desired yield.
\end{abstract}

Keywords: Endophytes, Vigna radiata, Plant Growth promotion, Bioinoculant

\section{INTRODUCTION}

Endophytes are the wide group of microorganisms that reside in the interior of host and adapt to its microenvironment. This habitat provides these microbes protection from environmental stresses, enables them to face lesser competition compared to other microbes. Endophytic bacteria interact more closely with the host plant in internal microenvironment of the plant tissue and are more bioactive than any other plant associated bacteria [1]. They can facilitate nutrient uptake of host plant, increasing plant hormone level or can have biocontrol effect [2]. Endophytes with Plant growth promoting capability also enables the associated plants to tolerate abiotic stresses like nutrient deficiency, drought, salt, elevated temperature [3]. Endophytes produce plant growth regulators like indole acetic acid, ACC Deaminase, fix atmospheric $\mathrm{N}_{2}$, produce siderophores, biocontrol agents, antibiotics and hydrogen cyanide, solubilize mineral phosphates and other minerals and thus improve plant growth and yield by interacting with host plants. Several nodule forming bacteria belonging to rhizobial species have been reported by researchers [4]. Non-rhizobial endophytes isolated from nodules and roots have also been reported for plant growth promotion [5] [6]. To meet the demand of increasing population for food, plant growth and yield, high input of chemicals is required [7]. Uncontrolled use of chemicals raises a number of concerns such as soil degradation, loss of biodiversity, water contamination and health risks for human and animals. This has led to the search for new promising bio inoculants.
Vigna radiata (mung bean) is one of the important crop of Kharif season in Madhya pradesh due to its short growing period. Mung bean belongs to the Papilionoideae family, order Leguminosae It is rich in proteins, minerals, and vitamins [8].The present work was aimed at the isolation and identification of plant growth promoting and antagonistic endophytic bacteria from Vigna radiata for their exploitation as bioinoculant in fields as substitute to chemical fertilizers.

\section{MATERIAL AND METHODS \\ 1. Isolation of endophytic bacteria}

For the isolation of bacterial endophytes, the nodules were collected from the roots of Vigna radiata from the field located near Misrod during summer and Kharif season. Nodules were detached from the roots using forceps, washed with tap water to remove adhering soil and then surface-sterilized using $70 \%$ ethanol followed by $0.1 \% \mathrm{HgCl}_{2}$ with intermittent washing with sterile water for the removal of traces of sterilant . Nodules were crushed in the sterile conditions in sterile eppendorf tube with the help of glass rod in sterile distilled water and the resulting turbid suspension was streaked on Tryptone soy agar (TSA) plates followed by incubation at $30^{\circ} \mathrm{C}$. After $24-36 \mathrm{~h}$, the colonies were picked and purified on TSA plates and maintained at $4^{\circ} \mathrm{C}$.

\section{Morphological Characteristics}

Colony morphology (shape, margin, elevation, colour) of the isolates were observed and Gram staining was performed. 


\section{International Journal of Research in Advent Technology, Vol.7, No.5, May 2019 E-ISSN: 2321-9637 \\ Available online at www.ijrat.org}

\section{PHYSIOLOGICAL CHARACTERISTICS}

\subsection{Temperature tolerance:}

All the isolates were streaked onto the respective medium and incubated at different temperature between $35-45^{\circ} \mathrm{C}$ for $24-48 \mathrm{~h}$ to examine the temperature tolerance ability of the isolates [9].

\section{$3.2 \mathrm{pH}$ tolerance:}

The ability of the bacterial isolates to grow in alkaline or acid media was assessed using respective agar medium at different $\mathrm{pH}$ range between., (3-10) (by using $1 \mathrm{~N} \mathrm{HCL}$ or $1 \mathrm{~N} \mathrm{NaOH}$ ) and incubated at $28 \pm 2{ }^{\circ} \mathrm{C}$ for 24 to $48 \mathrm{~h}$.

\subsection{Salt tolerance:}

Bacterial isolates were tested for their salt tolerance on respective medium supplemented with $1,2,3,4$ and 5 $\%(\mathrm{w} / \mathrm{v}) \mathrm{NaCl}[10]$.

\section{SCREENING OF PLANT GROWTH PROMOTING (PGP) PROPERTIES OF ENDOPHYTIC BACTERIAL ISOLATES}

The following PGP attributes of isolates were examined:

\subsection{Phosphate Solubilization:}

Phosphate solubilization ability of isolates was examined using Pikovaskya agar medium [11]. Isolates were spot inoculated onto the Pikovaskya agar plates and incubated at $28 \pm 2{ }^{\circ} \mathrm{C}$ for $24-48 \mathrm{~h}$. A clear zone formation around the spot indicated positive test. The diameter of zone of solubilization was measured and expressed in centimetres. To calculate the solubilization efficiency of bacterial isolate following formula was used

Solubilization Efficiency $(\%)=$ zone diameter $(\mathrm{z})$ colony diameter (n) X 100

Colony diameter (n)

\subsection{Indole -3 Acetic Acid (IAA) Production:}

IAA production by the bacterial isolates was examined, by inoculating the log phase cultures in broth amended with $5 \mathrm{mM} / \mathrm{L}$ tryptophan for $24 \mathrm{~h}$ [12]. Supernatant was collected after centrifugation at 10,000 rpm for $15 \mathrm{~min}$. $100 \mu \mathrm{l}$ of $10 \mathrm{mM} o$-phosphoric acid and $4 \mathrm{ml}$ of Salkowaski's reagent $\left(1 \mathrm{ml}\right.$ of $0.5 \mathrm{mM} \mathrm{FeCl}_{3}$ in $35 \%$ of $\mathrm{HClO}_{4}$ ) were added to $2 \mathrm{ml}$ of supernatant of each strain and incubated at room temprature for $25 \mathrm{~min}$ for development of pink colour. Absorbance was measured at $535 \mathrm{~nm}$ using UV-VIS spectrophotometer. Uninoculated broth with Salkowaski's reagent was used as control.

\subsection{HCN production:}

For determination of $\mathrm{HCN}$ (hydrogen cyanide) production log phase culture was streaked on agar plate of respective media amended with $4.4 \mathrm{~g} / 1$ glycine [13]. Filter paper soaked in $0.5 \%$ picric acid in $1 \% \mathrm{Na}_{2} \mathrm{CO}_{3}$ was placed in the lid of plates. The control plates were un-inoculated. The plates were sealed with parafilm and incubated at $28 \pm 2^{\circ} \mathrm{C}$ for $24-48 \mathrm{~h}$. Development of brown colour was noted as positive test for $\mathrm{HCN}$ production.

\subsection{Siderophore production:}

Siderophore production was examined on Chromeazurol S (CAS) medium following the method of [14]. Log phase cultures of isolated root nodule endophytic bacteria were spot inoculated on CAS agar plates and incubated at $28 \pm 2{ }^{\circ} \mathrm{C}$ for $24-48 \mathrm{~h}$. Formation of orangeyellow halo around the colonies indicated the positive test for production of siderophore.

\subsection{Ammonia production:}

Ammonia production was examined on peptone broth [15]. Log phase cultures of isolated endophytic bacteria were inoculated in peptone broth incubated at $28 \pm 2^{\circ} \mathrm{C}$ for $24-48 \mathrm{~h}$. Yellow to brown precipitate after adding few drops of Nessler's reagent indicated positive test. Uninoculated peptone broth served as control.

\subsection{ACC deaminase activity}

ACC (1-aminocyclopropane-1-carboxylate) deaminase producing bacterial isolates were detected qualitatively using Dworkin and Foster minimal medium simply known as DF medium. DF medium was supplemented $3 \mathrm{mM}$ 1-aminocyclopropane-1-carboxylate and bacterial isolates were streaked on the plates and incubated at $28^{\circ} \mathrm{C}$ for 72 hours. Simultaneously control was prepared by supplementing DF medium with ammonium sulfate $(2 \mathrm{~g} / \mathrm{l})$ to detect whether they utilized nitrogen source or not. Bacterial isolates were streaked upon it. Growth of bacterial isolates in medium supplemented with ACC indicated positive test for ACC deaminase production.

\subsection{Antagonistic activity}

Antagonistic properties of isolates were tested against Fusarium oxysporum (F.oxysporum), Macrophomina phaseolina (M.phaseolina), Sclerotenia sclerotiorum (S.sclerotiorum) by in vitro dual plate assay [16]. A loop full $\log$ phase culture (24h old) of each bacterial strain was spot inoculated at a distance around pregrown $5 \mathrm{~mm}$ agar disc containing mycelial growth of the fungal pathogen. Plates were incubated at $28 \pm 2{ }^{\circ} \mathrm{C}$ for 3-4 days. Formation of inhibition zone indicated positive test for antagonistic activity. 


\section{Available online at www.ijrat.org}

\section{RESULTS}

Investigations were carried out on bacterial endophytes isolated from roots nodules of Vigna radiata plants. The isolates were tested for their beneficial traits and potential applications like their ability to solubilise inorganic phosphate, production of plant growth promoting substances and antagonistic activity. The results obtained on these aspects are presented hereunder.

Table 1 Colony characteristics and Gram staining

\section{Colony Morphology and Gram Reaction}

Morphology of the recovered bacterial colonies on TSA were observed and various colony characteristics were analysed which are shown in Table 1 . The colour of the bacterial colonies was observed as white and pale white. All the isolates were Gram positive, short or long rods arranged in chain.

\begin{tabular}{|c|c|c|c|c|}
\hline S.No. & Isolate & Colony colour & Colony size & Gram reaction \\
\hline 1 & VRN1 & White & $2 \mathrm{~mm}$ & + \\
\hline 2 & VRN2 & White & $1 \mathrm{~mm}$ & + \\
\hline 3 & VRN3 & White & $2 \mathrm{~mm}$ & + \\
\hline 4 & VRN4 & Pale white & $1 \mathrm{~mm}$ & + \\
\hline 5 & VRN5 & Pale white & $1 \mathrm{~mm}$ & + \\
\hline 6 & VRN6 & Pale white & $1 \mathrm{~mm}$ & + \\
\hline 7 & VRN7 & Pale white & $1.2 \mathrm{~mm}$ & + \\
\hline 8 & VRN8 & Pale white & $1.5 \mathrm{~mm}$ & + \\
\hline 9 & VRN9 & yellow & $1 \mathrm{~mm}$ & + \\
\hline 10 & VRN 10 & Pale white & $1 \mathrm{~mm}$ & + \\
\hline 11 & VRN11 & Pale white & $2 \mathrm{~mm}$ & + \\
\hline 12 & VRN12 & Pale white & $2 \mathrm{~mm}$ & + \\
\hline 13 & VRN13 & Pale white & $1.5 \mathrm{~mm}$ & + \\
\hline 14 & VRN14 & yellow & $2 \mathrm{~mm}$ & + \\
\hline 15 & VRN15 & White & $1.5 \mathrm{~mm}$ & + \\
\hline 16 & VRN16 & White & $2 \mathrm{~mm}$ & + \\
\hline 17 & VRN17 & White & $2 \mathrm{~mm}$ & + \\
\hline 18 & VRN18 & Pale white & $1.5 \mathrm{~mm}$ & + \\
\hline 19 & VRN19 & White & $2 \mathrm{~mm}$ & + \\
\hline 20 & VRN20 & Pale white & $2 \mathrm{~mm}$ & + \\
\hline 21 & VRN21 & Pale white & $1 \mathrm{~mm}$ & + \\
\hline 22 & VRN22 & White & $1.5 \mathrm{~mm}$ & + \\
\hline
\end{tabular}


Available online at www.ijrat.org

\begin{tabular}{|l|l|l|l|c|}
\hline 23 & VRN23 & White & $1 \mathrm{~mm}$ & + \\
\hline 24 & VRN24 & Pale white & $1 \mathrm{~mm}$ & + \\
\hline 25 & VRN25 & White & $1.5 \mathrm{~mm}$ & + \\
\hline
\end{tabular}

\section{Temperature, $\mathrm{pH}$ and Salt Tolerance}

A total of 25 bacterial endophytic isolates were obtained from healthy root nodules of Vigna radiata plant. All the isolates were screened for growth at different temperatures $\left(35-45^{\circ} \mathrm{C}\right)$ and salt concentrations $(1-5 \%)$. At 35 to $40^{\circ} \mathrm{C}$, all the endophytic isolates showed growth while 6 isolates viz. VRN5 VRN7, VRN10, VRN13, VRN15 and VRN17 showed growth at $45^{\circ} \mathrm{C}$. All the endophytic isolates from nodules of mungbean showed growth at $1 \%$ salt concentration. At 2 and $3 \%$ salt concentration VRN1 and VRN13 isolates showed growth, respectively.4\% salt concentration was tolerated by isolates VRN4, VRN14, VRN15 and VRN17. Most of the bacterial isolates showed optimum growth at $\mathrm{pH} 7$. Isolates VRN4, VRN14 and VRN16 showed pH tolerance in range 6-7.5 whereas isolated VRN1 and VRN13 showed temperature tolerance between $\mathrm{pH} 6.5$ 8. VRN5 isolate tolerated $\mathrm{pH}$ in the range between 6-8. None of the isolates tolerated $\mathrm{pH}$ above 8 and below 6 . The outcomes suggest that isolates in present study can tolerate the variation in salinity and temperature and can tolerate both slight acidic and basic $\mathrm{pH}$ of soi.l thus these isolates can withstand in harsh environmental conditions in the soil.

Table 2. Temperature, $\mathrm{pH}$ and Salt Tolerance by recovered endophytes

\begin{tabular}{|c|c|c|c|c|}
\hline S. No. & Isolate & $\begin{array}{l}\text { Temperature tolerance (35- } \\
\left.\qquad 4^{\circ} \mathrm{C}\right)\end{array}$ & $\begin{array}{c}\text { Salt Tolerance upto (1- } \\
\mathbf{5 \%})\end{array}$ & $\begin{array}{l}\mathbf{p H} \\
\text { Tolerance } \\
(3-10)\end{array}$ \\
\hline 1 & VRN1 & 38 & 2 & $6.5-8$ \\
\hline 2 & VRN2 & 38 & 1 & 7 \\
\hline 3 & VRN3 & 38 & 1 & 7 \\
\hline 4 & VRN4 & 40 & 4 & $6-7.5$ \\
\hline 5 & VRN5 & 45 & 1 & $6-8$ \\
\hline 6 & VRN6 & 38 & 1 & 7 \\
\hline 7 & VRN7 & 45 & 1 & 7 \\
\hline 8 & VRN8 & 40 & 1 & 7 \\
\hline 9 & VRN9 & 40 & 1 & 7 \\
\hline 10 & VRN 10 & 45 & 1 & 7 \\
\hline 11 & VRN11 & 40 & 1 & 7 \\
\hline 12 & VRN12 & 40 & 1 & 7 \\
\hline 13 & VRN13 & 45 & 3 & $6.5-8$ \\
\hline 14 & VRN14 & 40 & 4 & $6-7.5$ \\
\hline 15 & VRN15 & 45 & 4 & 7 \\
\hline
\end{tabular}


Available online at www.ijrat.org

\begin{tabular}{|l|l|l|l|l|}
\hline 16 & VRN16 & 38 & 1 & $6-7.5$ \\
\hline 17 & VRN17 & 45 & 4 & 7 \\
\hline 18 & VRN18 & 38 & 1 & 7 \\
\hline 19 & VRN19 & 40 & 1 & 7 \\
\hline 20 & VRN20 & 40 & 1 & 7 \\
\hline 21 & VRN21 & 40 & 1 & 7 \\
\hline 22 & VRN22 & 38 & 1 & 7 \\
\hline 23 & VRN23 & 38 & 1 & 7 \\
\hline 24 & VRN24 & 38 & 1 & 7 \\
\hline 25 & VRN25 & 38 & 1 & 7 \\
\hline
\end{tabular}

\section{PGP properties of endophytic bacterial isolates}

\section{Phosphate solubilisation}

Plants have evolved several strategies to release and acquire $P_{i}$ from the soil which results in an increased root: shoot ratio by accelerating lateral root growth and produces long root hairs to increase the volume of soil exposed. $\mathrm{P}$ deficiency also stimulates $\mathrm{P}_{\mathrm{i}}$ transporter proteins, and promotes the exudation of organic acids, RNases, and phosphatases thereby mobilizing $\mathrm{P}$ from insoluble compounds or complexes [17]. All the bacterial endophytes were tested for their ability to solubilize inorganic phosphate on Pikovskayas agar plates. Only nine isolate out of twenty five were found to be positive for solubilization of phosphate. The Phosphate solubilization efficiency of bacterial cultures ranged from 25.8 to 61.2 percent. Maximum P. solubilization efficiency was recorded for isolate VRN18 (61.2\%) and minimum for VRN5 (25.8\%). The results are shown in Table 3 .

\section{IAA Production}

The mechanism mostly employed by plant growth promoting rhizobacteria (PGPR) on plant is via production of plant hormone IAA. IAA induces physiological activities such as plant cell division and root initiation [18]. The IAA production was detected using Salkowasky reagent. Positive result was indicated by development of pink colour and amount of IAA produced was determined colorimetrically using a standard curve. The isolates were found to produce IAA in amount ranging from 1.02 to 44.24 $\mu \mathrm{g} / \mathrm{ml}$. Maximum IAA production was detected in isolate VRN5 $(44.24 \mu \mathrm{g} / \mathrm{ml})$ and minimum by VRN25 $(1.02 \mu \mathrm{g} / \mathrm{ml})($ Table 2$)$

\section{HCN Production}

Hydrogen cyanide is a volatile compound exhibiting antifungal activity protecting plants against various soil borne pathogens and help in plant growth indirectly [19]. There are several reportson $\mathrm{HCN}$ production by endophytes [20]. 52\% of the bacterial endophytes studied here also showed positive result for $\mathrm{HCN}$ production which indicates their potential as antagonistic against soil borne fungal pathogens.

\section{Siderophore Production}

Microorganisms produce low molecular weight ironchelating molecules called "siderophores" having high affinity for $\mathrm{Fe}^{3+}$. Siderophores are responsible for the solubilization as well as transport of this vital element into microbial cells. Since siderophores are produced in Iron scarcity it results in death of pathogens due to iron deprivation. Production of siderophore by bacterial endophytes was screened by CAS plate assay. Appearance of orange halo around bacterial colony indicates siderophore production. Fifteen isolates out of twenty five were found to be positive for siderophore production. Production of siderophore by bacterial isolates was also detected quantitatively and the amount of siderophore produced ranged from 0.09 to 5.22 $\mathrm{mg} / \mathrm{ml}$. The results obtained are shown in Table 3

\section{Ammonia Production}

It has been reported by various workers that inoculation with $\mathrm{NH}_{3}$ producing bacteria may improve the plant growth due to their ability to fix nitrogen $\left(\mathrm{N}_{2}\right)$ to ammonia $\left(\mathrm{NH}_{3}\right)$ making it available to plant for growth [21]. In this study also ammonia production was noted in some of the endophytic bacteria which depict their nitrogen fixing capability. In this study nine isolates i.e.36\% of isolates were found positive for Ammonia production.

\section{ACC Deaminase Production}




\section{Available online at www.ijrat.org}

1-Aminocyclopropane-1 carboxylate is an immediate precursor of ethylene in plants, and its production is highly dependent on endogenous levels of ACC [22]. Microorganisms having enzyme ACC-deaminase breaks down ACC into ammonia and $\alpha$-ketobutyrate in spite of its conversion into ethylene. Some of the bacterial endophytes from root nodules of Vigna radiata are found positive for ACC-deaminase activity which could decrease the amount of ACC, and consequently that of ethylene. Reduction in ethylene level decreases the inhibitory effects of higher ethylene concentrations [23]. In our study all the above mentioned PGP properties were observed; this indicates the potential of these bacterial endophytes for use as bioinoculants.

Bacterial isolates were tested for their ability to produce the enzyme ACC deaminase and utilize the compound 1-aminocyclopropane-1-carboxylate.Only thirteen bacterial isolates were able to produce ACC deaminase and utilize the compound 1-aminocyclopropane-1carboxylate; which was determined on the basis of their ability to grow on media supplemented with ACC.52\% of the isolates were positive for ACC deaminase production. However, rest of the isolates failed to grow on this media Table 3.

\section{Antagonistic Activity}

Antagonistic bacteria play an important role for the control of soil borne pathogens which account for major loss in yield to farmers. Production of siderophores, antibiotics like $2, \quad 4$ diacetylphloroglucinol, $\mathrm{HCN}$ and phytohormones are the mechanism responsible for antagonistic activity of the major group of bacteria. Some of the isolated bacterial endophytes showed high degree of antagonism against all the three fungal plant pathogens tested, which depicts their possible use as biocontrol agent for field application. All the bacterial isolates were screened for their antagonistic activity in vitro against three fungal pathogens i.e. Fusarium oxysporum, Macrophomina phaseolina, Sclerotinia sclerotiorum with the help of dual culture technique. The isolates VRN7, VRN10 and VRN15 inhibited the growth of all the three test fungus. Isolate VRN8 inhibited the growth of Fusarium oxysporum and Macrophomina phaseolina but could not affect the growth of, Sclerotinia sclerotiorum. IsolateVRN3 only inhibited the growth of fungi Fusarium oxysporum. VRN19 and VRN20 inhibited the growth of Sclerotinia sclerotiorum and did not have any effect on the growth of rest of the two fungus (Table 3)

Table 3 PGP properties by recovered endophytes.

\begin{tabular}{|c|c|c|c|c|c|c|c|c|}
\hline $\begin{array}{l}\text { S. } \\
\mathbf{N} \\
\text { o. }\end{array}$ & Isolate & $\begin{array}{c}\text { P. Sol } \\
\text { efficiency } \\
(\%)\end{array}$ & $\begin{array}{c}\text { IAA } \\
(\mu \mathrm{g} / \mathrm{ml})\end{array}$ & $\begin{array}{l}\text { Siderophore } \\
(\mathrm{mg} / \mathrm{ml})\end{array}$ & $\begin{array}{l}\text { HCN } \\
\text { Prod. }\end{array}$ & $\begin{array}{c}\text { ACC } \\
\text { Deaminase } \\
\text { activity }\end{array}$ & $\begin{array}{c}\text { Ammonia } \\
\text { Production }\end{array}$ & $\begin{array}{c}\text { Antagonism } \\
\text { against }\end{array}$ \\
\hline 1 & VRN1 & --- & $5.74 \pm 0.07$ & $5.22 \pm 0.02$ & --- & --- & --- & M. phaseolina \\
\hline 2 & VRN2 & 57.14 & --- & --- & --- & + & --- & --- \\
\hline 3 & VRN3 & 28.8 & --- & ---- & + & + & --- & F. oxysporum \\
\hline 4 & VRN4 & --- & $6.76 \pm 0.07$ & $0.75 \pm 0.06$ & + & + & + & --- \\
\hline 5 & VRN5 & 25.80 & $\begin{array}{l}44.23 \pm \\
0.09\end{array}$ & $2.93 \pm 0.01$ & + & ---- & + & --- \\
\hline 6 & VRN6 & --- & $\begin{array}{l}41.75 \pm \\
0.05\end{array}$ & --- & --- & --- & --- & --- \\
\hline 7 & VRN7 & --- & --- & $\overline{---}$ & --- & + & --- & $\begin{array}{l}\text { M. phaseolina, } \\
\text { S.sclerotorium } \\
\text { F. oxysporum }\end{array}$ \\
\hline 8 & VRN8 & 57.14 & --- & $2.96 \pm 0.01$ & + & + & + & $\begin{array}{l}\text { F. oxysporum } \\
\text { M. phaseolina }\end{array}$ \\
\hline 9 & VRN9 & --- & $2.02 \pm 0.09$ & $5.22 \pm 0.02$ & --- & --- & --- & $\overline{---}$ \\
\hline 10 & VRN10 & 41.66 & --- & --- & + & --- & --- & $\begin{array}{l}\text { M. phaseolina, } \\
\text { S. sclerotorium } \\
\text { F. oxysporum }\end{array}$ \\
\hline
\end{tabular}




\section{Available online at www.ijrat.org}

\begin{tabular}{|l|l|l|l|l|l|l|l|l|}
\hline 11 & VRN11 & 56 & --- & -- & + & --- & --- & --- \\
\hline 12 & VRN12 & --- & --- & --- & + & + & --- & --- \\
\hline 13 & VRN13 & 47.82 & $2.04 \pm 0.11$ & $3.51 \pm 0.11$ & + & --- & + & --- \\
\hline 14 & VRN14 & --- & $\begin{array}{l}40.54 \pm \\
0.11\end{array}$ & $0.39 \pm 0.01$ & + & --- & --- & --- \\
\hline 15 & VRN15 & 33.33 & $5.77 \pm 0.09$ & $0.66 \pm 0.09$ & --- & --- & --- & $\begin{array}{l}\text { M. phaseolina }, \\
\text { S. sclerotorium } \\
\end{array}$ \\
& & & & & & & F. oxysporum \\
\hline 16 & VRN16 & --- & $5.72 \pm 0.09$ & $1.84 \pm 0.11$ & + & + & + & --- \\
\hline 17 & VRN17 & --- & $44.24 \pm$ & $0.51 \pm 0.01$ & --- & + & --- & --- \\
\hline 18 & VRN18 & 61.29 & $\begin{array}{l}0.11 \\
0.53 \pm\end{array}$ & $0.81 \pm 0.09$ & + & + & --- & --- \\
\hline 19 & VRN19 & --- & $40.54 \pm$ & --- & + & --- & + & S. sclerotorium \\
\hline 20 & VRN20 & --- & $1.04 \pm 0.11$ & $1.17 \pm 0.09$ & + & --- & --- & S. sclerotorium \\
\hline 21 & VRN21 & --- & $\begin{array}{l}41.74 \pm \\
0.07\end{array}$ & $0.27 \pm 0.01$ & -- & + & + & --- \\
\hline 22 & VRN22 & --- & $3.53 \pm 0.11$ & --- & + & --- & --- & --- \\
\hline 23 & VRN23 & --- & $\begin{array}{l}44.23 \pm \\
0.09\end{array}$ & --- & + & + & --- & --- \\
\hline 24 & VRN24 & --- & $1.05 \pm 0.12$ & $0.72 \pm 0.01$ & --- & + & + & --- \\
\hline 25 & VRN25 & --- & $1.02 \pm 0.09$ & $0.09 \pm 0.01$ & --- & + & + & --- \\
\hline
\end{tabular}

'---' denotes that activity was not detected

\section{CONCLUSION}

The application of plant growth promoting bacterial endophytes as bio-inoculants may be a feasible preference to chemical fertilizers to increase the productivity of Vigna radiata and other crops. These bacterial endophytes possess various plant growth promoting traits, therefore these should be tested for other crops for achieving success for better crop yield as well as for the maintenance of soil fertility. The most important character of these isolates which generates novelty in their nature is that they can tolerate variations of $\mathrm{pH}$, temperature and salinity and help in countries like India, where there is huge biodiversity amongst various agro-climatic zones. In the above context, it may be concluded that these endophytic isolates have multiple PGP traits therefore such endophytes could be a better choice to be selected for the use as bioinoculant for field application. Further studies on the potential of these endophytes could be assessed by pot trial on different crop plants.

\section{REFERENCES}

[1] J.M. Dalal and N. Kulkarni. "Antagonistic and plant growth promoting potentials of indigenous endophytic bacteria of soybean (Glycine $\max (\mathrm{L})$ Merril)". Curr Res Microbiol Biotechnol 1(2): 6269. 2013.
[2] B.R. Glick. "Plant Growth-Promoting Bacteria: Mechanisms and Applications". Scientifica 1-15. 2012

[3] B. Jha; I. Gontia and A. Hartmann. "The roots of the halophyte Salicornia brachiata are a source of new halotolerant diazotrophic bacteria with plant growth-promoting potential”. Plant Soil 3:56:265277. 2012.

[4] P. Suneja; S.Piplani ; P. Dahiya and S.S. Dudeja. "Molecular characterization of mesorhizobia forming nodules on reverted non nodulating selection and normal cultivar of chickpea". J Agr Sci Tech 18(3): 763-773. 2016.

[5] N. Gujar; S. Singh and A. Prakash. "Enhancement in growth and alkaloid content in trigonella foenumgraecum by non-rhizobial root nodule endophytes".Int. J of recent trends in Sci. and tech. 296-303.2018.

[6] S.S Dudeja and R. Giri. "Beneficial properties, colonization, establishment and molecular diversity of endophytic bacteria in legumes and nonlegumes". African J Microbiol Res 8 (15): 1562 1572. 2014.

[7] D. Tilman; K.G. Cassman; P.A .Matson, R. Naylor and S. Polasky. "Agricultural sustainability and intensive production practices". Nature 418 (6898): 671-677. 2002. 


\section{E-ISSN: 2321-9637 \\ Available online at www.ijrat.org}

[8] H. Watanabe; Y Inaba; K. Kimura; S. Asahara and Y Kido. Dietary Mung Bean Protein Reduces Hepatic Steatosis, Fibrosis, and Inflammation in Male Mice with Diet-Induced, Nonalcoholic Fatty Liver Disease. J Nutr. 147(1):52-60. 2017.

[9] M. Jida and F. Assefa. "Phenotypic and plan growth promoting characteristics of Rhizobium leguminosarum bv. viciae from lenil growing areas of Ethiopia.” African J. Of Biotech. 5:4133-4142. 2011.

[10] S.Ben Romdhane; H. Nasr; R. Samba-Mbaye; M. Neyra; M.H. Ghorbel and P. De Lajudie. "Genetic diversity of Acacia tortilis ssp. raddiana rhizobia in Tunisia assessed by $16 \mathrm{~S}$ and $16 \mathrm{~S}-23 \mathrm{~S}$ rDNA genes analysis.” J. Appl. Microbiol., 100:436-445. 2006.

[11] R.I. Pikovskaya. "Mobilization of phosphorus in soil in connection with the vital activity of some microbial species". Mikrobiologya. 17:362370.1948 .

[12] J.M. Bric; R.M. Bostoc and S.E. Silverstone. "Rapid in situ assay for indole acetic acid production by bacteria immobilized on a nitrocellulose membrane." Appl. Environ. Microbiol. 57:534-538. 1991.

[13] A.W Bakker and B. Schippers . "Microbial Cyanide Production in the Rhizosphere in Relation to Potato Yield Reduction and Pseudomonas SPPMediated Plant Growth-Stimulation." Soil Biol.and Biochem. 19, 451-457.1987.

[14] B. Schwyn and J.B. Neilands. "Universal chemical assay for the detection and determination of siderophores." Anal.Biochem.160: 47-56. 1987.

[15] H.E. Lennette; A. Balows; W. J. Hauser et. al. "Collection, Handling and Processing of Specimen." In: Manual of Clinical Microbiology, 4th ed, ASM, Washington, DC, 73-98.1985.

[16]H.C. Huang and J.A.C. Hoes. "Penetration and infection of Sclerotinia sclerotiorum by Coniothyrium miniatus." Can. J. Bot. 54:506-410. 2008.

[17] K.G. Raghothama. "Phosphorus." In: Plant nutritional genomics (eds. M.R. Broadly and P.J. White) pp. 112-126, Blackwell, Oxford.2005.

[18]H. Panchal and S. Ingle. "Isolation and characterization of endophytes from the root of medicinal plant Chlorophytum borivilianum (Safedmusli)." J Adv. Dev. Res. 2: 205-209. 2011.

[19] A. Ramette; Y. Moënne-Loccoz and G. Défago. "Prevalence of fluorescent pseudomonas producing antifungal phloroglucinols and/or hydrogen cyanide in soils naturally suppressive or conducive to tobacco black root rot." FEMS Microbiol Ecol. 44:35-43. 2003.

[20] A. A Rodrigues; M.V. Forzani; R.D.S Soares., et al."Isolation and selection of plant growthpromoting bacteria associated with sugarcane." Pesqui Agropecuária Trop. 46:149-158. 2016.
[21]L. Ngoma,;K. Mogatlanyane and O.O. Babalola. "Screening of endophytic bacteria towards the development of cottage industry." In: An in Vitro Study. J Hum Ecol. 47(1):45-63. 2014.

[22] T.A. McKeon; N.E. Hoffmann and S.F. Yang. "The effect of plant-hormone pretreatments on ethylene production and synthesis of 1aminocyclopropane-1-carboxylic acid in waterstressed wheat leaves." Planta. 155: 437-443.1982.

[23] B.R. Glick ."The enhancement of plant growth by free living rhizobacteria." Can. J. Micrbiol. 41:109117.1995 . 